\title{
副鼻腔炎とロキシスロマイシン少量長期投与
}

\author{
宇野 芳史・斎藤 龍介 \\ 波多野 篤・金谷 真
}

\section{Long-Term Low-Dose Roxithromycin (RXM) Therapy for Chronic Sinusitis}

\author{
Yoshifumi Uno, Ryusuke Saito, Atsushi Hatano and Makoto Kanatani \\ (Okayama Saiseikai General Hospital)
}

\begin{abstract}
Seventeen adult patients with chronic sinusitis, who had been operated on or received conservative therapy for a long time but still complained of nasal symptoms, were treated with $150 \mathrm{mg}$ roxithromycin (RXM) per day for 6 months or more.

1) Significant improvement both in nasal symptoms and in rhinoscopic findings was noted after 6 months, little improvement after 1 month of therapy.

2) Great subjective improvement in nasal obstruction was noted, and volume and quality of nasal discharge showed objective improvement.

3) No significant side effects were noted in any of the patients during this therapy.

4) Long-term, low-dose RXM therapy was effective even when RXM-resistant bacteria were present. Therefore, this effect was not considered to be associated with its antibacterial activity but with some as not yet unknown mechanism.
\end{abstract}

Key words: chronic sinusitis, long-term low-dose therapy, roxithromycin

\section{緒 言}

近年, びまん性沉細気管支炎 (DPB) に対す るエリスロマイシン $(\mathrm{EM})$ の少量長期投与の有 効性が報告されている1) 3)。そして，これらの 症例に打いては，気管支病变のみならず，高率 に合併している副鼻腔病変に対しても改善がみ られると報告され4)5), 耳鼻咽喉科領域でも慢 性副鼻腔炎6)7) 和よび滲出性中耳炎8) に対して $\mathrm{EM}$ 少量長期投与が有効であると報告されてい る.

最近, EM 誘導体として, 従来の $\mathrm{EM}$ の欠点 であった胃酸に不安定で, 経口投与で十分な吸
収が得られないといら点を改良したロキシスロ マイシン $(\mathrm{RXM})$ が開発された(図 1)。これは, $\mathrm{EM}$ と同じく14員環マクロライド系抗生物質で あり, EMの 9 位の carbonyl 基が 2-methoxyethoxy-methyloxime で置換されたものである. 従来のマクロライド系抗生剂と比べて, 胃酸抵 抗性に優れ，経口投与で体内移行が良好であり， 血中濃度半減期が長い点が特徵である910). こ のため EM と異なり 1 日 2 回投与で十分な血 中濃度が得られるとされている. 過去, 慢性副 鼻腔炎に対して, 通常量の投与による抗生物質 としての薬効の検討11) は行われているが， 
$\mathrm{EM}$ 少量長期投与と同じ治療概念による検討は 行われていない。

今回我々は, 成人の難治性慢性副鼻腔炎患者 に対してこの RXM 少量長期投与 (150 mg/日) を行い，その臨床効果について検討を行ったの で報告する。

\section{対 象}

対象症例は，1991年 8 月以降に RXM 少量 長期投与を開始した慢性副鼻腔炎患者17例であ る. 内訳は男性 9 例, 女性 8 例, 年齢は 46 歳か ら80歳で平均 66.2 歳であった(図 2 ).これらは, 過去に保存的あるいは外科的治療 (手術療法を 含む)を行ったにもかかわらず，鼻漏，鼻閉， 後鼻漏などの症状が存続していた症例である.

\section{方法}

$\mathrm{RXM}$ を 1 日 1 回 $150 \mathrm{mg}$ 食後経口投与とし， 投与期間は，原則として 6 カ月とした。また， 本剂の投与期間中は原則として他剂の併用は行 わず，急性増悪期のみ他の抗生剂を併用した。

対象症例の自覚症状を鼻閉, 鼻漏, 後鼻漏, 嗅覚障害执よび頭重頭痛の 5 項目につき，また 他覚所見を, 鼻粘膜の腫脹, 鼻汁の量, 鼻汁の 性状拈よび後鼻漏の 4 項目について 4 段階で評 価し，その重症度を表現した。また，その効果
判定は, 菊地ら 6 の方法にならい, 投与前後に 扣ける評点を比較することにより，著明改善， 改善, やや改善执よび不変として検討した（表 1 ). 短期効果の判定を投与開始後 1 力月目に, 長期効果の判定を投与開始後 6 力月目で行っ $た^{6)}$. また, 中鼻道分泌物からの菌の分離培養 および感受性検査により細菌学的検討を行った。

\section{結果}

$\mathrm{RXM}$ の少量長期投与 $(1$ 日 1 回 $150 \mathrm{mg}$ 経口 投与， 6 カ月）を完了した17例について，その 臨床経過を観察した．RXM に起因すると考え られる副作用は 1 例も認められなかった。

\section{1 . 短期効果}

投与開始後 1 カ月目の時点で効果判定を行い,

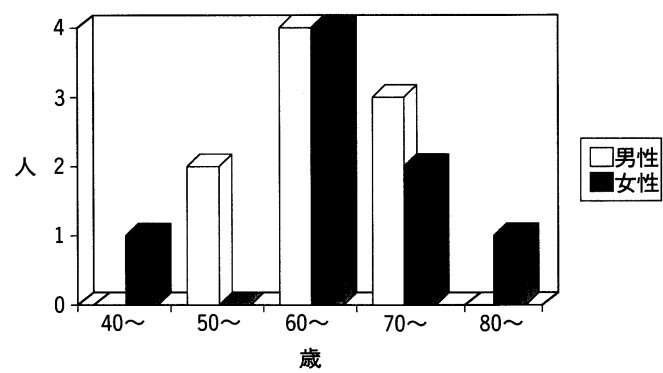

図 2 年齢性別分布
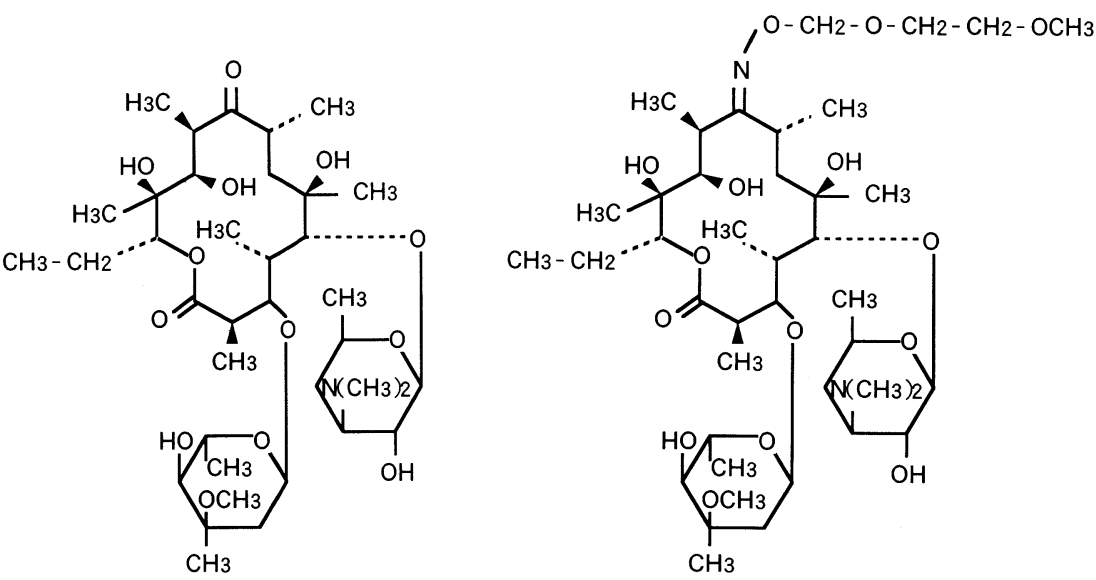

図 $1 \mathrm{EM} と \mathrm{RXM}$ の構造式 
改善以上の評価が得られた症例を有効とすると， 有効率は，自覚症状においては，鼻閉 $35.7 \%$, 鼻漏 $14.3 \%$, 後鼻漏 $21.4 \%$, 嗅覚障害 $0 \%$, 頭 重頭痛 $40.0 \%$ であった。一方，他覚所見に掠い ては, 鼻粘膜の腫脹 $0 \%$, 鼻汁の量 $13.3 \%$, 鼻 汁の性状 $13.3 \%$, 後鼻漏 $20 \%$ で, 自覚症状, 他 覚所見とも有効率は各項目とも低かった（図 3 ).

\section{2 . 長期効果}

投与開始後 6 力月目の時点で最終効果判定を 行い, 短期効果と同様, 改善以上の評価が得ら れた症例を有効とすると, 有効率は, 自覚症状 に扣いては, 鼻閉 $75.0 \%$, 鼻漏 $46.2 \%$, 後鼻漏 $50.0 \%$, 嗅覚障害 $0 \%$, 頭重頭痛 $44.4 \%$ で, 鼻
閉の改善が目立った。一方，他覚所見において は, 鼻粘膜の腫脹 $15.4 \%$, 鼻汁の量 $53.8 \%$, 鼻 汁の性状 $61.5 \%$, 後鼻漏 $53.8 \%$ で, 鼻汁の性状, 量, 後鼻漏の改善が目立った(図 4 ).

\section{3 . 細菌学的検討}

本療法施行前に細菌学的検査を行ったのは17 例中 8 例であり, それらの症例の検出菌は, Pseudomonas aeruginosa 2 例, Staphylococcus aureus, Streptococcus pneumoniae, Flavobacterium meningoseptics 各 1 例, 検出菌なし 3 例であった (表 2 ). これらのらち RXM に感受性が認められ たのはStreptococcus pneumoniaeの 1 例のみで, 他の 4 例はいずれも感受性が認められなかった.

表 1 自覚症状 - 他覚所見の評価項目と効果判定基準

\begin{tabular}{c|c|c|c|c|c}
\hline 評 & \multicolumn{5}{|c}{ 自覚症状 } \\
\cline { 2 - 6 } 点 & 鼻閉 & 鼻漏 & 後鼻漏 & 嗅覚障害 & 頭重頭痛 \\
\hline 3 & 不通 & いつも鼻をかむ & 常にある & 全くにおわない & 強くて持続 \\
2 & よくつまる & よくかむ & よくある & 少しにおいがわかる & 時々中断 \\
1 & 時々つまる & 時々かむ & 時々ある & ほぼにおいがわかる & 時々ある \\
0 & なし & なし & なし & なし & なし
\end{tabular}

\begin{tabular}{c|c|c|c|c}
\hline 評 & \multicolumn{4}{|c}{ 他覚所見 } \\
\cline { 2 - 5 } 点 & 鼻粘膜の腫脹 & 㐭汁の量 & 鼻汁の性状 & 後鼻漏 \\
\hline 3 & 高度 & 多量 & 膿性 & 多量 \\
2 & 中等度 & 中等度 & 粘膿性 & 中等度 \\
1 & 軽度 & 少量 & 粘性 & 少量 \\
0 & なし & なし & 漿液性またはなし & なし
\end{tabular}

[効果判定基準]

1. 著明改善 : 有症状項目の評点が 0 になったもの。( $3 \rightarrow 0,2 \rightarrow 0,1 \rightarrow 0)$

2. 改善 :有症状項目の評点が 2 段階軽減するも 0 にいたっていないもの。 $(3 \rightarrow 1)$

3. やや改善 : 有症状項目の評点が 1 段階軽減するも0にいたっていないもの。 $(3 \rightarrow 2,2 \rightarrow 1)$

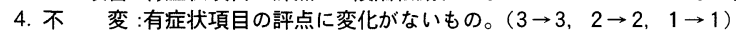

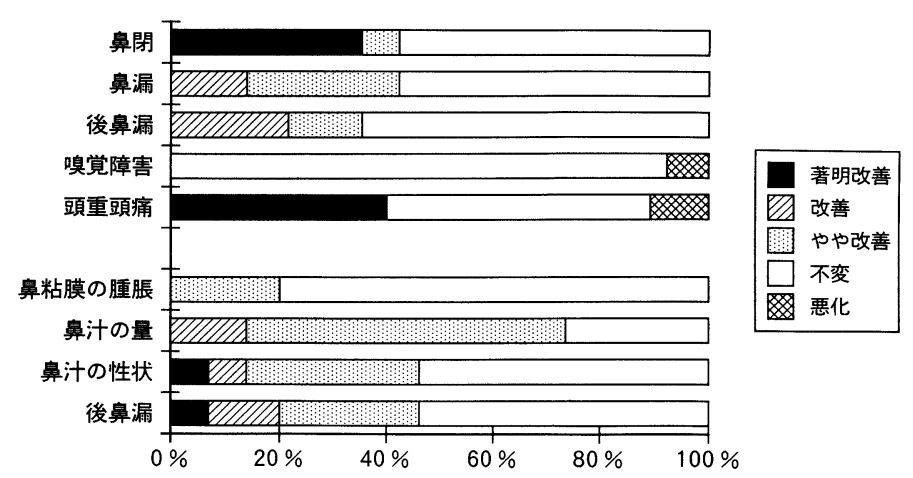

図 $3 \mathrm{RXM}$ 投与開始後 1 力月目の自覚症状 (上段) と 他覚所見(下段)の項目別改善度 


\section{4. 代表的症例}

今回の検討に拉いて効果の認められた代表的

な 2 症例を提示する.

症例 1.72 歳, 女性.

主訴 : 鼻漏, 鼻閉, 後鼻漏.

既往歴 : 53歳の時, 左副鼻腔根本術.

現病歷 : 術後鼻症状はなく経過良好であった が, 1988年12月頃から鼻漏, 鼻閉, 後鼻漏の鼻 症状があり, 当科にて, CCL, NFLX 等の抗生 剂, プロナーゼ, カルボシステイン等の消炎酵 素剤, 気道粘膜修復剤の保存的治療を続けたが, 症状の改善がみられず，1991年11月 RXM 150 $\mathrm{mg} /$ 日投与を開始した.

鼻腔所見 : 左鼻腔に鼻茸, 両鼻腔に粘稠な鼻 漏が多量に認められた。

鼻副鼻腔 $\mathrm{CT}$ 像 : 左上顎洞には術後陰影があ り，右上顎洞にも軟部陰影が充満していた(図 5 ).

血液検査 : CHA x512, IgG $1574 \mathrm{mg} / \mathrm{dl}, \mathrm{IgA}$ $336 \mathrm{mg} / \mathrm{dl}, \mathrm{IgM} 86 \mathrm{mg} / \mathrm{dl}$.

臨床経過：投与開始後 2 力月目から鼻漏, 鼻 閉ともに改善が認められ，投与開始後 4 力月目 には後鼻漏も改善し，6 カ月目投与終了時には 鼻副鼻腔 CT 上で, 右上顎洞に認められていた 陰影が消失した（図 5 ). 投与終了時の血液検査 では，免疫グロブリンには変化が認められなか ったが，CHA x64 と著明に低下した. RXM 投
与中には, 副作用は全く認められなかった. 投 与終了後 4 カ月が経過したが, 症状の再発はな く経過良好である。

症例 2.63 歳, 女性.

主訴 : 鼻漏, 鼻閉, 後鼻漏, 無嗅症.

既往歴 : 特記すべきことなし.

現病歴: 1985年頃から, 鼻漏, 鼻閉, 後鼻漏 あり, 近医にて保存的に加療していた。症状が 改善せず, 無嗅症も出現してさたため, 1990年 2 月当科受診. SBTPS, NFLX 等の抗生剂, 塩化リゾチーム消炎酵素剤の保存的治療および 上顎洞穿刺洗浄などの外科的療法を行うも症状 の改善がみられず, 1991年 8 月 RXM $150 \mathrm{mg} /$ 日投与を開始した。

鼻腔所見 : 両側鼻腔には粘稠な鼻汁が充満し ていた。

鼻副鼻腔 CT 像 : 両側管骨蜂巣に軟部陰影が 認められた(図6)。 . た両側上顎洞にも陰影が 認められたが, 内部には空気陰影も認められた。

細菌検査 : Pseudomonas aeruginosa が検出さ

表 2 中鼻道の検出菌

\begin{tabular}{ll}
\hline \hline Pseudomonas aeruginosa & 2 例 \\
Staphylococcus aureus & 1 例 \\
Streptococcus pneumoniae & 1 例 \\
Flavobacterium meningoseptics & 1 例 \\
検出菌なし & 3 例
\end{tabular}

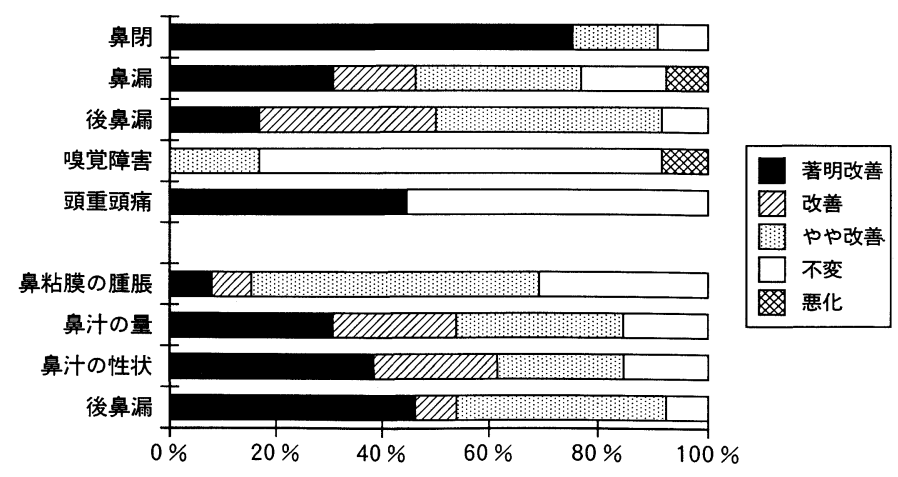

図 $4 \mathrm{RXM}$ 投与開始後 6 力月目の自覚症状 (上段) と 他覚所見(下段)の項目別改善度 
れたが RXM に対する感受性は認められなか った。

血液検查 : CHA x512, IgG $1506 \mathrm{mg} / \mathrm{dl}, \mathrm{IgA}$ $272 \mathrm{mg} / \mathrm{dl}$, IgM $42 \mathrm{mg} / \mathrm{dl}$.

臨床経過：投与開始後 1 力月目から鼻汁の量 は減少し, 4 力月目には鼻閉, 後鼻漏も注济消 失した。 6 力月投与終了時には, 鼻副鼻腔 $\mathrm{CT}$ では，上顎洞の陰影には変化がみられなかった が，両側篩骨蜂巣の陰影は改善を示していた （図 6 ）。投与終了時の血液検査では，免疫グロ ブリンには変化が認められなかったが，CHA はx256 と改善していた。投与終了後 6 カ月が 経過したが，症状の再発はなく経過良好である。

\section{考察}

最近，DPB 抽よび慢性副鼻腔炎に対して， $\mathrm{EM}$ 少量長期投与療法の有効性が報告されてい
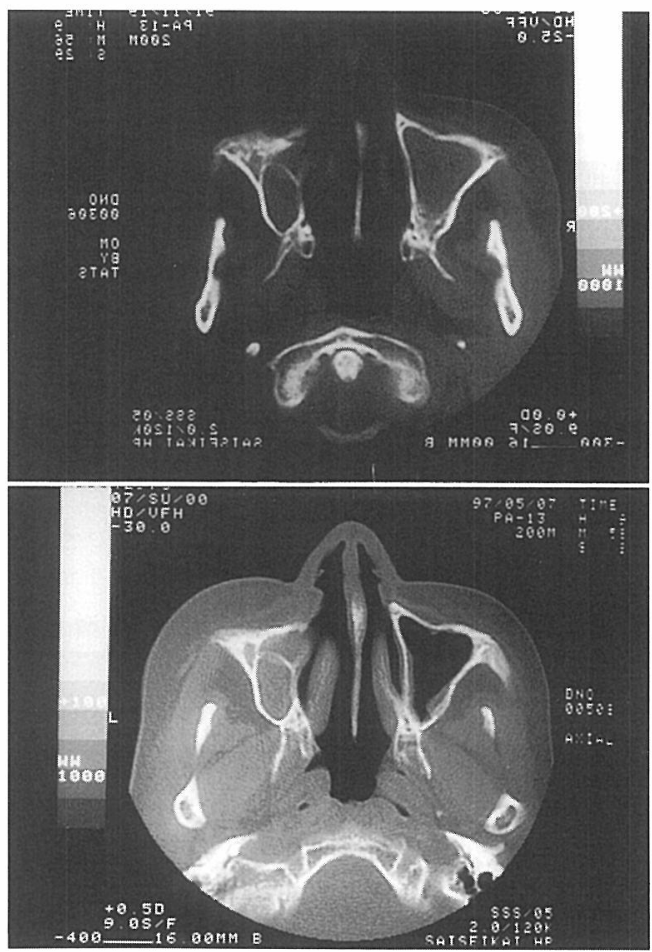

図 5 鼻副鼾空 CT

上 : RXM 投与前

下: RXM 投与開始後 6 力月目
るが，これらの慢性気道感染症に対して $\mathrm{EM}$ がどのように作用して効果を発現するかについ ては未だ十分には解明されていない。ただ，本 治療法の臨床観察から次のような興味ある事実 が知られている。(1)効果発現に長期間を要する が，効果は確実で持続性があること，(2)投与さ れた EM の血中濃度や組織濃度は起炎菌に対 する MIC に遙かに及ばない低濃度にもかかわ らず効果が文られること, (3)菌の陰性化や交代 現象がみられないことの 3 点である1) 3)。すな わち，本治療法による臨床症状の改善は EM による起炎菌の排除の結果ではなく，持続的感 染によって生じた気道粘膜の炎症性状態に対す る生体の免疫動態に関与して効果を現している ことが推測されている。

今回我々は, 慢性副鼻腔炎患者17例に対して
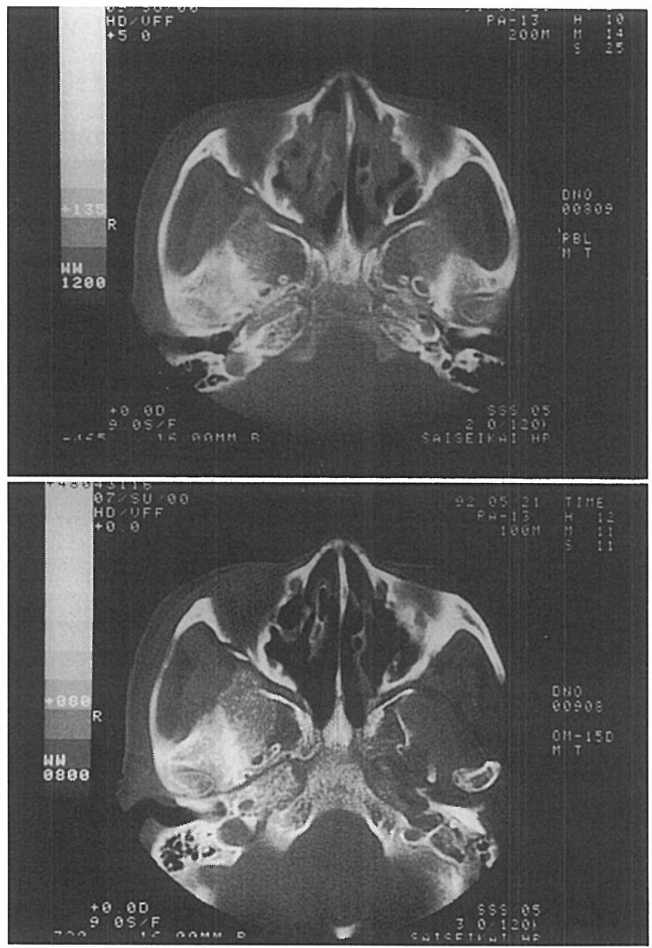

図 6 鼻副鼻腔 $\mathrm{CT}$ 上: RXM 投与前 下 : RXM 投与開始後 6 力月目 
$\mathrm{EM}$ と同じ14員環マクロライド系抗生剂 RXM の少量長期投与を行い，その治療効果を検討し た. 6 カ月間の経口投与を完了した17例につい てその有効性を投与開始後 1 力月目拉よび 6 力 月目の 2 回にわたって検討したが，投与開始後 1 力月目の短期観察では自覚症状, 他覚所見と b その改善度は低く，投与開始後 6 力月目の長 期観察ではじめて自覚症状, 他覚所見の各項目 での改善が高率に認められた。これらの結果か ら，RXM 少量長期投与は慢性副鼻腔炎の治療 に EM と同様，十分効果があることが確認さ れた。長期投与効果で検討すると，他覚的に鼻 粘膜の腫脹は $15.4 \%$ でしか改善していないにも かかわらず，自覚症状としての鼻閉は $75.0 \% の$ 症例で改善していた。これは後鼻漏や鼻汁の量 や性状に著しい改善がみられ，これが鼻腔の通 気性の改善をもたらしたものと推察される。す なわち，慢性副鼻腔炎に対する本治療法の臨床 効果は, $\mathrm{EM}$ 少量長期投与で菊地ら ${ }^{6)}$ が報告し ている成績と類似して括り，RXM 少量長期投 与が EM のそれと同じ作用機序で有効性を現

していると推察された。

本来, マクロライド系抗生剤は細菌のリボ ゾームに作用してその蛋白合成を阻害すること により抗菌作用を現すとされているが12)13)，我 我の今回の RXM 投与法は通常量 (300 mg/日) の半量であり, その臨床効果を単なる抗菌作用 に求めることには無理がある. 特に症例 2 のよ らにRXM に感受性を示さないPseudomonas aeruginosa が起炎菌となっている症例に拈い ても鼻閉, 鼻漏, 後鼻漏などの鼻症状の改善が 著明に認められた症例が多く，本治療法の作用 機序は抗菌作用以外のものに求めるべきであろ う. 最近, EM および RXM など14員環の基本 骨格を持つマクロライド系抗生剂の投与による

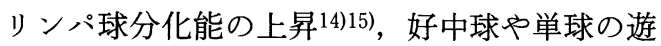
走能の元進, 活性酸素産生能, サイトカイン産 生能(6) 20) の増強などが報告され, 更に, リン 㛏21), 線毛細胞22), 粘液産生細胞 ${ }^{23)}$ などにも 影響を与えることが明らかにされてさた。従っ
て，これらの細胞賦活性が，気道の持続性感染 に基づく慢性炎症病態を抑制し，気道の過分泌 状態を改善して持続性のある臨床効果を現して くるとの考え方が有力である.いずれにしても， 今回の RXM 少量長期投与は種々の治療に抵 抗する難治性慢性副鼻腔炎に対して有効な治療 法の一つであると思われ，更に EM と比較し て RXM は 1 日 1 回の内服でよく, 外来患者 の長期治療薬として用い易く, 今後試みる価值 のある治療薬であると考えられた。

\section{まとめ}

1. 種々の治療に抵抗する慢性副鼻腔炎患者 17例に対し RXM 少量長期投与療法 (1 日 1 回 $150 \mathrm{mg}$ 経口投与， 6 力月)を行った.

2. 鼻症状括よび鼻腔所見とも投与開始後 1 カ月目の短期観察ではあまり改善がみられなか ったが， 6 カ月目の長期観察では著明に改善し ていた.

3. 自覚症状では鼻閉の改善が著しく, 他覚 所見では鼻汁の量拉よび性状の改善が著しかっ た。

4.RXM に起因すると考えられる副作用は 認められなかった。

5.RXM に対して感受性のない検出菌に対 しても効果が認められ，本治療法の効果は単な る RXM の抗菌作用に由来するものではない ことが推察された。

\section{文献}

1）工藤翔二，木村 亿，植竹健司，他：び慢性沉 細気管支炎に対するマクロライド系抗生剂の少 量長期投与の臨床効果. 日胸疾会誌 22 増 : 254, 1984.

2) 田口善夫, 岩田猛邦, 種田和清, 他 : 慢性下気 道感染症の EM 療法 一長期投与例の検討一. 厚生省特定疾患, びまん性肺疾患調査研究班昭 和63年度研究報告書. 148 150頁, 1989 .

3）工藤翔二, 山口哲生, 倉島篤行, 他 : びまん性 沉細気管支炎に対するェリスロマイシン療法の 臨床効果 (関東地区多施設検討)。厚生省特定疾 患, びまん性肺疾患調查研究班昭和63年度研究 報告書. 157 159頁, 1989. 
4）澤木政好，三笠桂一，阿児博文，他：副鼻腔気 管支症候群に扣ける Erythromycin 長期治療の 副鼻腔炎症状に与兄る影響について. Chemotherapy $36: 440,1988$.

5）洲崎春海, 杉田公一, 工藤翔二, 他: エリス口 マイシンはなぜびまん性沉細気管支炎に効くの かーびをん性沉細気管支炎に併発する慢性副 鼻腔炎に対する効果一. Therapeutic Reseach $11: 29 \sim 31,1990$.

6）菊地 茂, 洲崎春海, 青木彰彦, 他 : 副鼻腔炎 とェリスロマイシン少量長期投与. 耳鼻臨床 $84: 41 \sim 47,1991$.

7）高北晋一, 北村溥之, 大八木章博, 他 : 慢性副 鼻腔炎と少量エリスロマイシン療法. 耳鼻臨床 $84:$ 489 498, 1991.

8）飯野ゆき, 杉田公一, 石戸谷淳一, 他 : 小児 參出性中耳炎のエリスロマイシン療法. 耳鼻臨 床 $85: 713 \sim 720,1992$.

9) Grassi C and Bertoletti : Roxithromycin (RU 28965) in the treatment of respiratory tract infections. Chemoterapia $6: 41 \sim 44,1987$.

10) Bertrand A and Caubarrere I : Multicentre comparative study of the efficacy and safety of roxithromycin and erythromycin ethylsuccinate in the treatment of lower respiratory tract infections. Br J Clin Pract 42 Suppl 55 : 98 99, 1988.

11）河村正三, 馬場駿吉, 板橋隆嗣, 他 : 慢性副鼻 腔炎に対する Roxithromycin (RU 28965) の薬 効評価. 耳鼻 $35: 103 \sim 112,1989$.

12) Fournet MP, Zini R, Deforges L, et al : Determination of binding parameters of macrolides, lincosamides, and streptogramins to Legionella pneumophili. J Pharm Sci 76 : 153 156, 1987.

13) Kuenzi B, Segessenmann $C H$ and Gerber $A U$ : Postantibiotic effect of roxithromycin, erythromycin, and clindamycin against selected Gram-positive bacteria and Haemophilus influenzae. J Antimicrob Chemother 20 Suppl B : 39 46, 1987.

14) Van Rensburg CEJ, Anderson A, Joone G, et al : Effect of erythromycin on cellular and humoral immune functions in vitro and in vivo. J Antimicrob Chemother $8: 467 \sim 474,1981$.
15) Andrson R, Van Rensburg CEJ and Eftychis H: Further studies on erythromycin effects on cellular immune functions in vitro and in vivo ; enhancement of neutrophil motility by erythromycin combined with ascorbate or thiamine. J Antimicrob Chemother $10: 409 \sim$ 417, 1982.

16) Anderson R : Erythromycin and Roxithromycin potentiate human neutrophil locomotion in vitro by inhibition ofleukoattractant activated superoxide generation and autooxidation. J Infect Dis 159 : 966 973, 1989.

17) Takeshita $K$, Yamagishi I, Harada $M$, et al : Immunological and anti-inflammatory effects of clarithromycin ; inhibition of interleukin 1 production of murine peritoneal macrophage. Durgs Exptl Clin Res 15 : 527 533, 1989.

18) Naess A and Solberg CO : Effects of two macrolide antibiotics on human leukocyte membrane receptors and functions. APMIS 96 : 503 508, 1988.

19）林 雅晴, 野間 剛, 前田和一: 各種抗生物質 （ロキシスロマイシン，セファクロル，アズト レオナム, オフロキサシン)の好中球機能賦活 作用についての比較検討. 診と薬 $28: 133 \sim 137$, 1991.

20）金野真一, 足立 満, 河津謙太, 他：ロキシス ロマイシンのウイルス, 細菌混合感染に打よぼ す作用について.臨床薬理 $23: 243 \sim 244,1992$.

21）三笠桂一, 澤木正好, 古西 満, 他 : 慢性下気 道感染症患者に拈けるェリスロマイシン治療の Natural Killer 細胞活性に与える影響. 感染症 誌 $63: 811 \sim 815,1989$.

22）玉置 淳, 武山 廉, 千代谷厚, 他: 気道粘膜 上皮の線毛運動に対するロキシスロマイシンの 効果とその作用機序に関する検討. 呼吸と循環 $39:$ 481 485, 1991.

23) Goswami SK, Kivity $S$ and Marom $Z$ : Erythromycin inhibits respiratory glycoconjugate secretion from human airway in vitro. Am Rev Respir Dis 141 : 72 78, 1990.

$$
\left(\begin{array}{l}
\text { 原稿受付 : 平成 } 4 \text { 年 } 10 \text { 月 } 30 \text { 日 } \\
\text { 原稿採択 : 平成 } 4 \text { 年11月 } 10 \text { 日 急載 } \\
\text { 別刷請求先 : 宇野芳史 } \\
\text { 个700 岡山市伊福町 } 1-17-18 \\
\text { 岡山済生会総合病院耳鼻咽喉科 }
\end{array}\right)
$$

